\title{
Influence of hypoxia and irradiation on osteopontin expression in head and neck cancer and glioblastoma cell lines
}

Gisela Wohlleben ${ }^{1}$, Agmal Scherzad ${ }^{2}$, Antje Güttler ${ }^{3}$, Dirk Vordermark ${ }^{3}$, Sebastian Kuger ${ }^{1,4}$, Michael Flentje ${ }^{1}$ and Buelent Polat ${ }^{1 *}$

\begin{abstract}
Background: Tumor hypoxia is a known risk factor for reduced response to radiotherapy. The evaluation of noninvasive methods for the detection of hypoxia is therefore of interest. Osteopontin (OPN) has been discussed as an endogenous hypoxia biomarker. It is overexpressed in many cancers and is involved in tumor progression and metastasis.

Methods: To examine the influence of hypoxia and irradiation on osteopontin expression we used different cell lines (head and neck cancer (Cal27 and FaDu) and glioblastoma multiforme (U251 and U87)). Cells were treated with hypoxia for $24 \mathrm{~h}$ and were then irradiated with doses of 2 and $8 \mathrm{~Gy}$. Osteopontin expression was analyzed on mRNA level by quantitative real-time RT-PCR (qPCR) and on protein level by western blot. Cell culture supernatants were evaluated for secreted OPN by ELISA.

Results: Hypoxia caused an increase in osteopontin protein expression in all cell lines. In Cal27 a corresponding increase in OPN mRNA expression was observed. In contrast the other cell lines showed a reduced mRNA expression under hypoxic conditions. After irradiation OPN mRNA expression raised slightly in FaDu and U87 cells while it was reduced in U251 and stable in Cal27 cells under normoxia. The combined treatment (hypoxia and irradiation) led to a slight increase of OPN mRNA after 2 Gy in U251 (24 h) and in U87 (24 and 48 h) cell lines falling back to base line after $8 \mathrm{~Gy}$. This effect was not seen in Cal27 or in FaDu cells. Secreted OPN was detected only in the two glioblastoma cell lines with reduced protein levels under hypoxic conditions. Again the combined treatment resulted in a minor increase in OPN secretion 48 hours after irradiation with 8 Gy.

Conclusion: Osteopontin expression is strongly modulated by hypoxia and only to a minor extent by irradiation. Intracellular OPN homeostasis seems to vary considerably between cell lines. This may explain the partly conflicting results concerning response prediction and prognosis in the clinical setting.
\end{abstract}

Keywords: Osteopontin, Hypoxia, Irradiation, Head and neck cancer, Glioblastoma multiforme

\section{Background}

Tumor hypoxia is a known risk factor for reduced response to radiotherapy [1]. In these studies hypoxia was measured with invasive polarographic $\mathrm{O}_{2}$ needle electrodes. The evaluation of noninvasive methods for the detection of hypoxia is of interest. One strategy is the use of imaging modalities like PET/CT or MRI. Common

\footnotetext{
*Correspondence: polat_b@ukw.de

'Department of Radiation Oncology, University hospital Wuerzburg,

Josef-Schneider-Straße 11, 97080 Würzburg, Germany

Full list of author information is available at the end of the article
}

PET tracers for hypoxia imaging which were used in clinical trials are 18-F-MISO, 18-F-FAZA and $62-\mathrm{Cu}$ ATSM [2-4].

Another way to investigate tumor hypoxia is the search for hypoxia associated biomarkers which can be detected from blood samples or tumor tissues. Several studies investigated the role of HIF- $1 \alpha$ and its dependent gene regulation including CA IX and VEGF [1, 5-7]. One of these so called endogenous hypoxia markers is osteopontin (OPN) [8], a secreted glycophosphoprotein which is overexpressed in many cancer types [9]. It plays an important

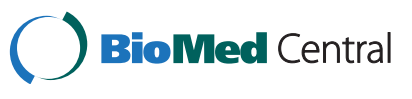

(c) 2015 Wohlleben et al. Open Access This article is distributed under the terms of the Creative Commons Attribution 4.0 International License (http://creativecommons.org/licenses/by/4.0/), which permits unrestricted use, distribution, and reproduction in any medium, provided you give appropriate credit to the original author(s) and the source, provide a link to the Creative Commons license, and indicate if changes were made. The Creative Commons Public Domain Dedication waiver (http://creativecommons.org/publicdomain/zero/1.0/) applies to the data made available in this article, unless otherwise stated. 
role in tumor progression, angiogenesis and metastasis formation [10]. Furthermore, OPN is a prognostic marker for different tumor entities in which elevated plasma levels are associated with an unfavorable prognosis [11-15]. In head and neck cancer treated with definitive radiotherapy Petrik et al. demonstrated prolonged overall survival and event free survival in patients with OPN levels below median [11]. Similar results were shown by Overgaard et al. and Snitcovsky et al. $[13,16]$. However, the TROG 02.02 phase III trial did not report any correlation between osteopontin levels and tumor control or patient outcome [17].

To look at possible intervening variables we analyzed the influence of irradiation on OPN expression under normoxic and hypoxic conditions in head and neck cancer and glioblastoma cell lines.

\section{Methods}

\section{Cell culture}

The human tumour cell lines Cal 27 (tongue carcinoma), FaDu (hypopharyngeal carcinoma), U251 and U87 (both derived from glioblastoma multiforme) were purchased from the American Type Culture Collection (ATCC, Manassas, VA, USA). Cells were grown in Dulbecco's modified Eagle`s medium (DMEM) supplemented with $10 \%$ fetal bovine serum (PAA, Cölbe Germany), $2 \mathrm{mM}$ L-glutamine and penicillin $(100 \mathrm{IU} / \mathrm{ml}) /$ streptomycin $(100 \mu \mathrm{g} / \mathrm{ml})$ under normoxic standard conditions $(21 \%$ $\mathrm{O}_{2}, 5 \% \mathrm{CO}_{2}$ at $37{ }^{\circ} \mathrm{C}$ ).

To compare OPN expression under normoxic and hypoxic standard conditions at mRNA or protein levels cells were seeded on Petri dishes at a concentration of $8 \times 10^{5} /$ dish (Cal 27) or $1 \times 10^{6} /$ dish (FaDu, U87, U251). Standard condition for hypoxic treatment of cells is normally at $0.1 \%$ oxygen concentration in radiobiology. Afterwards cells were allowed to adhere before part of them were transferred into a hypoxic glove box (Invivo 2 200, Ruskinn technology limited, Leeds, UK) and cultured at $0.1 \% \mathrm{O}_{2}\left(5 \% \mathrm{CO}_{2}\right.$ at $37{ }^{\circ} \mathrm{C}$; FaDu, U87, U251) or $1.0 \%\left(5 \% \mathrm{CO}_{2}\right.$ at $37{ }^{\circ} \mathrm{C}$; $\left.\mathrm{Cal} 27, \mathrm{FaDu}\right)$ for 24 hours. Since the Cal27 cells did not survive under $0.1 \% \mathrm{O}_{2}$ concentration for more than 24 hours (which is the incubation time required before irradiation) we conducted the experiments under less hypoxic conditions with $1 \%$

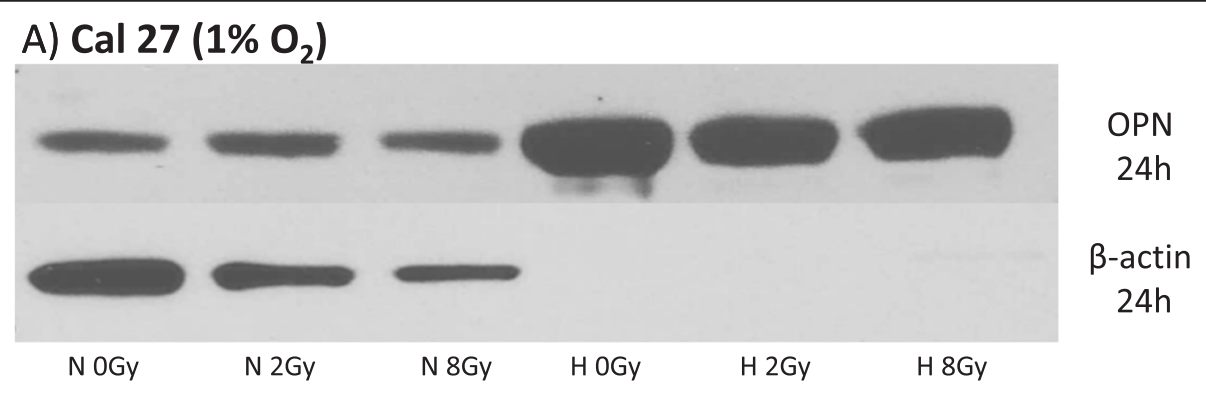

B) $\mathrm{FaDu}\left(1 \% \mathrm{O}_{2}\right)$

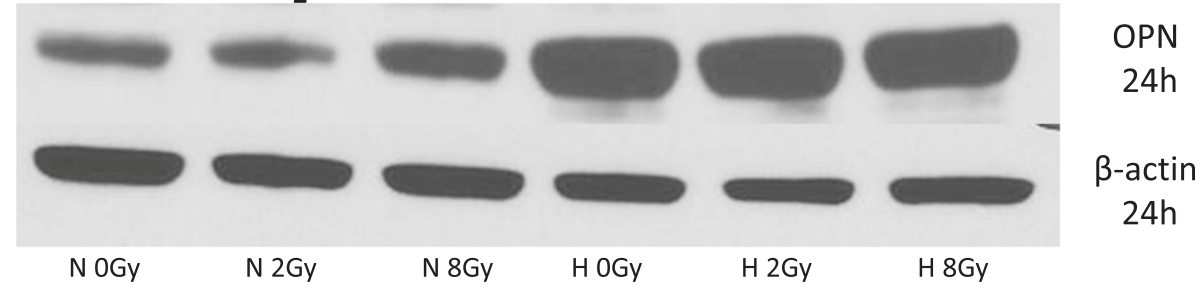

C) $\mathrm{FaDu}\left(0.1 \% \mathrm{O}_{2}\right)$

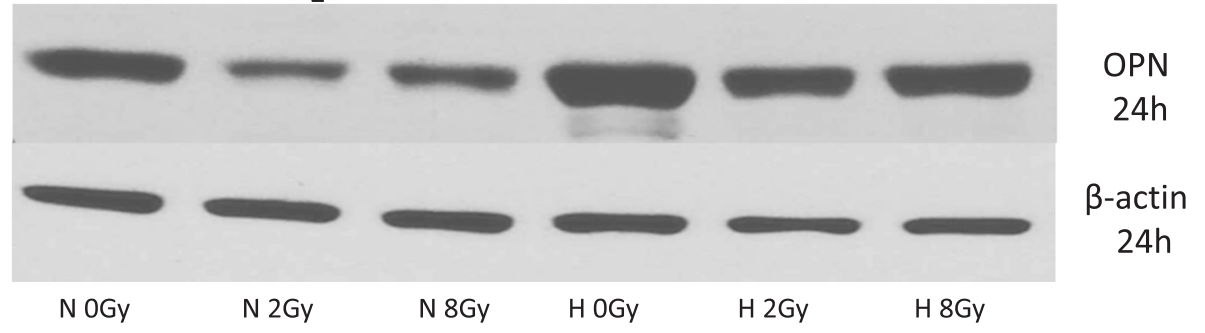

Fig. 1 Western blot showing OPN protein expression under normoxic $\left(\mathrm{N}=21 \% \mathrm{O}_{2}\right)$ and hypoxic $\left(\mathrm{H}=1 \% \mathrm{O}_{2}\right.$ or $\left.0.1 \% \mathrm{O}_{2}\right)$ conditions $24 \mathrm{~h}$ after irradiation with 0, 2 and $8 \mathrm{~Gy}$ in $\mathrm{Cal} 27$ (a) and FaDu (b), (c) head and neck cancer cell lines. Hypoxic conditions were $1 \%$ O for both cell lines. FaDu cells were also treated with $0.1 \% \mathrm{O}_{2}$ (c) showing comparable results 
$\mathrm{O}_{2}$. For a better comparability of the hypoxic treatment in the head and neck cancer cell lines we repeated the western blot and qPCR analysis in the FaDu cell line with $1 \% \mathrm{O}_{2}$. In parallel cells were kept under normoxic conditions. Twenty-four hours later cells were irradiated at doses of $2 \mathrm{~Gy}$ and 8 Gy (still under hypoxic or normoxic conditions) using a 6MV linear accelerator (Siemens, Concord, CA, USA) at a dose rate of $2 \mathrm{~Gy} / \mathrm{min}$ or left untreated. After 24 or 48 hours post irradiation growing under standard or hypoxic conditions respectively, cells were harvested for preparing whole-cell lysates or RNA.

\section{Western blot analysis}

Whole-cell lysates were prepared by lysing cells in RIPA buffer under standard conditions. Proteins were run on 4-12 \% Bis-Tris gradient gels (Invitrogen, Karlsruhe, Germany), electrophoretically transferred to polyacrylamide membranes (Invitrogen) and analyzed by Western blotting. Polyclonal rabbit anti-human-OPN antibody FL314 and monoclonal mouse anti-human-HPRT antibody were obtained from Santa Cruz Biotechnology, Inc. (Heidelberg, Germany). Mouse monoclonal antibodies against $\beta$-actin and GAPDH were purchased from Sigma (Deisenhofen, Germany) and abcam (Cambridge, UK). Detection was achieved using species-specific horseradish peroxidase-coupled secondary antibodies (DAKO, Hamburg, Germany) and Amersham ${ }^{\mathrm{Tm}}$ ECL $^{\mathrm{Tx}}$ Select Western blotting detection reagent (GE Healthcare, Chalfont St. Giles, Buckinghamshire, UK).

\section{ELISA for osteopontin detection in supernatants}

Osteopontin protein levels in the non-concentrated supernatants of cultured cells, collected after indicated durations of hypoxia, with or without irradiation, were determined by ELISA, using the Human Osteopontin Assay Kit-IBL (Immuno-Biological Laboratories Co., Ltd.) according to the manufacturer's instructions.

\section{RNA isolation and quantitative real-time PCR (qPCR)}

RNA of the cells was isolated using the RNeasy ${ }^{\circ}$ Mini Kit as recommended by the manufacturer (Qiagen, Hilden,

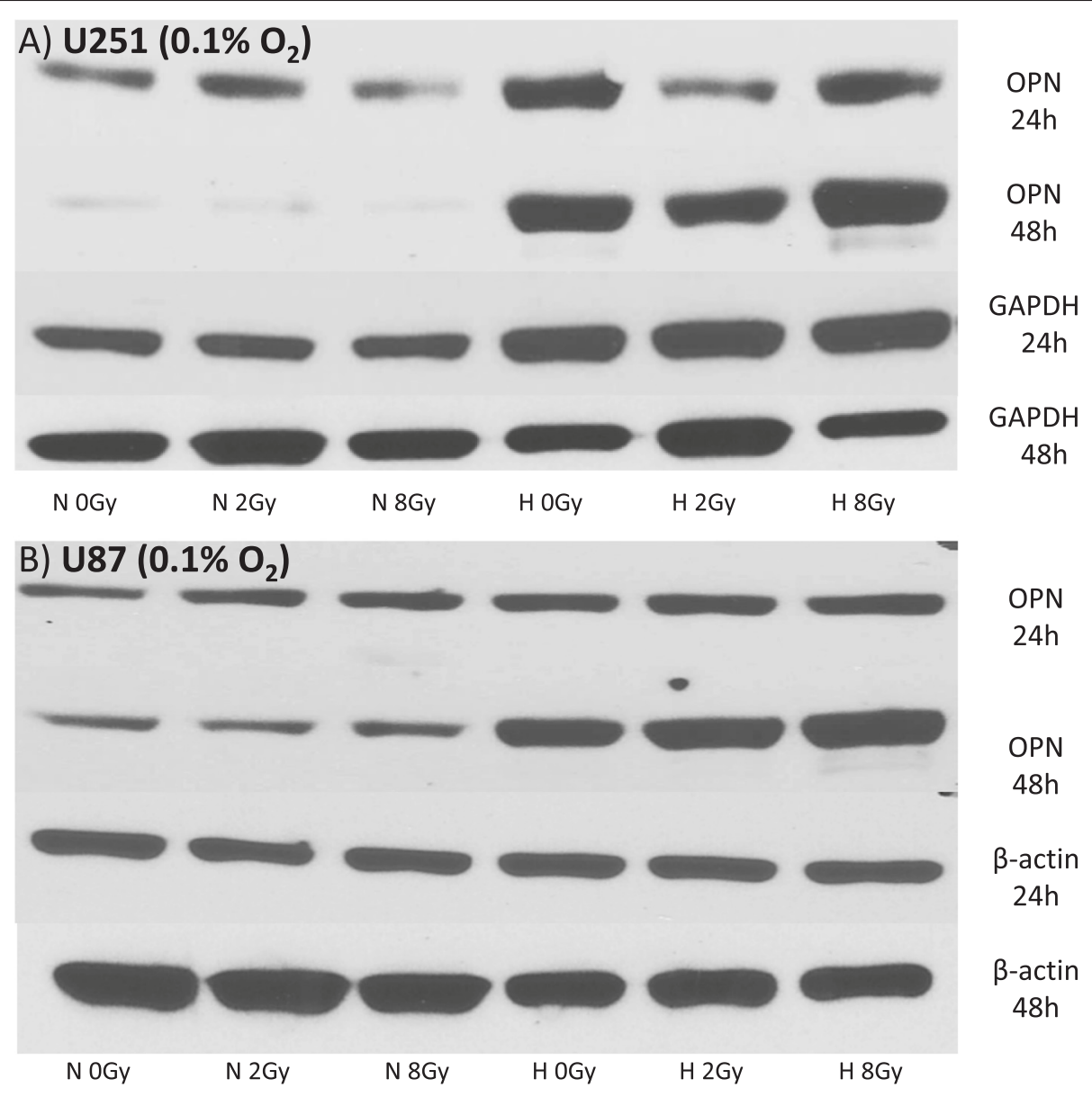

Fig. 2 Western blot showing OPN-expression under normoxic ( $\left.\mathrm{N}=21 \% \mathrm{O}_{2}\right)$ and hypoxic $\left(\mathrm{H}=0.1 \% \mathrm{O}_{2}\right)$ conditions $24 \mathrm{~h}$ and $48 \mathrm{~h}$ after irradiation with 0, 2 and 8 Gy in U251 (a) and U87 (b) glioblastoma cell lines 
Germany). Afterwards RNA was reverse transcribed into cDNA using First Strand cDNA Synthesis Kit (Fermentas $\mathrm{GmbH}$, St. Leon-Rot, Germany) following the instructions given by the suppliers. To amplify cDNA coding for OPN and the housekeeping gene hypoxanthine phosphoribosyltransferase (HPRT), quantitative real-time-PCR was carried out using TaqMan ${ }^{\circ}$ Gene Expression Assays (Applied Biosystems, Foster City, CA, USA). To verify that the hypoxic culture conditions were sufficient CA IX qPCR analysis was performed in the same way. The cycle number crossing the threshold was used as the threshold cycle $\left(C_{t}\right)$. The amount of cDNA in each sample was normalized to the crossing point of the housekeeping gene hypoxanthine phosphoribosyltransferase (HPRT). Changes in the expression were detected and quantified using the comparative CT method $\left(2^{-\Delta \Delta C t}\right)$.

\section{Statistics}

All experiments were carried out in triplicate and reproduced 2 times. Data are presented as means $( \pm$ standard deviation). Statistical analysis was performed using ANOVA between groups. Significance level was set at $\mathrm{p}<0.05$.

\section{Results}

Effect of hypoxia and irradiation on OPN expression protein level

Two different head and neck cancer cell lines (tongue carcinoma cell line, CAL 27 and hypopharyngeal cancer cell line $\mathrm{FaDu}$ ) and two glioblastoma cell lines (U251 and U87) were cultured under different oxygen conditions $\left(1 \% \mathrm{O}_{2}\right.$ for $\mathrm{Cal} 27$ and $\mathrm{FaDU}$ and $0.1 \% \mathrm{O}_{2}$ for U251 and U87). Furthermore, a possible effect on OPN expression caused by irradiation (2 Gy or 8 Gy) was investigated. Twenty-four hours (all cell lines) and 48 hours (U251, U87) after irradiation, lysates of the different cell lines were prepared and tested by Western blot analysis for OPN protein levels. Twenty-four hours after irradiation a clear increase of OPN protein expression was seen in all cell lines grown under hypoxic conditions compared with normoxic controls. Except for $\mathrm{FaDu}$ and $\mathrm{U} 251$ cells grown at $0.1 \% \mathrm{O}_{2}$, this effect was independent of additional irradiation (Figs. 1 and 2). Irradiation of $\mathrm{FaDu}$ with doses of 2 and 8 Gy apparently had a weak inhibitory effect of OPN levels under hypoxic standard culture conditions $\left(0.1 \% \mathrm{O}_{2}\right)$. This was also seen in U251 cells under hypoxia and 24 h post irradiation with
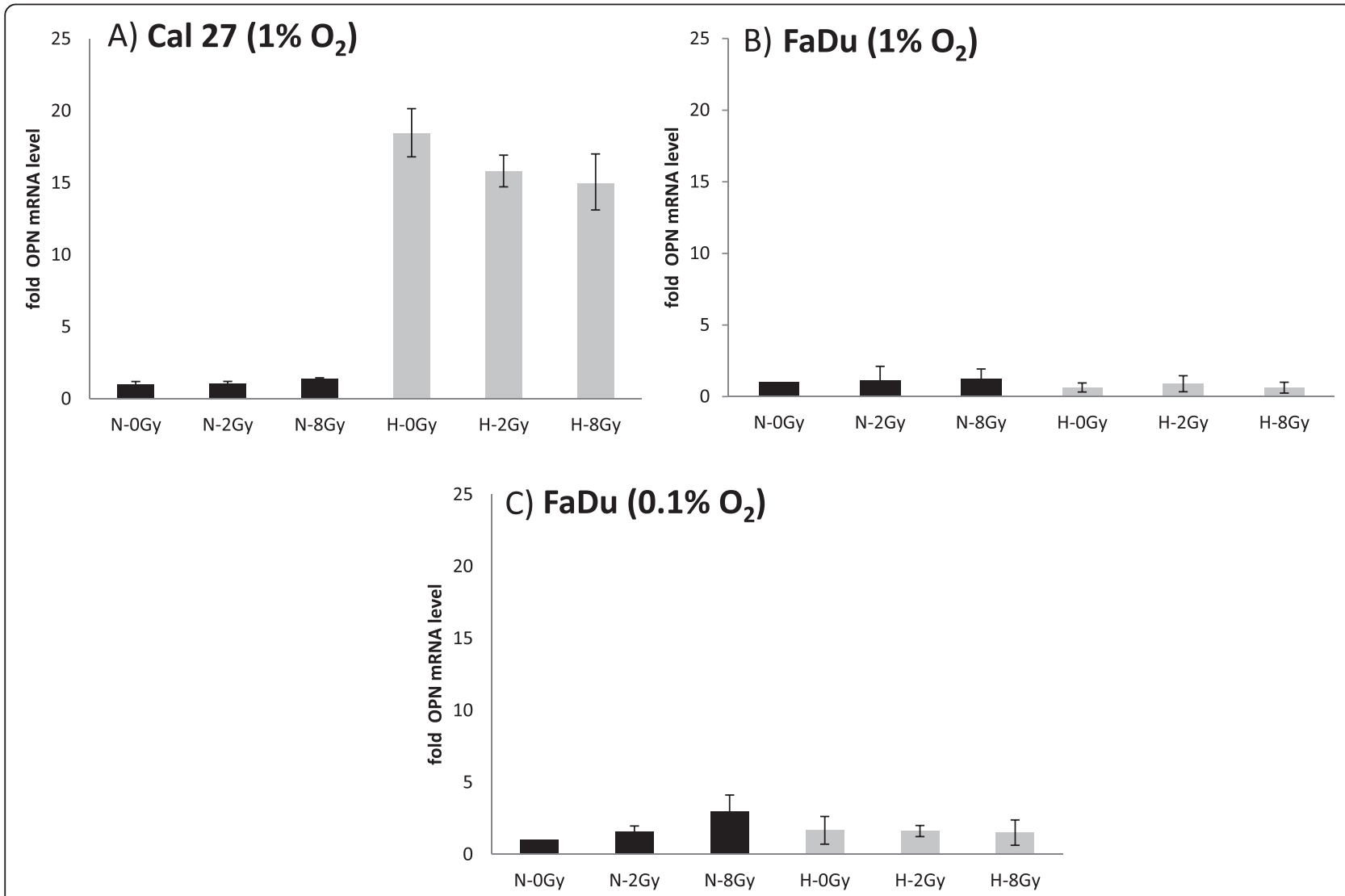

Fig. 3 Quantitative real-time RT-PCR data showing OPN RNA expression under normoxic $\left(\mathrm{N}=21 \% \mathrm{O}_{2}\right)$ and hypoxic $\left(\mathrm{H}^{2}=1 \% \mathrm{O}_{2}\right.$ or $\left.0.1 \% \mathrm{O}_{2}\right)$ conditions $24 \mathrm{~h}$ after irradiation with 0, 2 and 8 Gy in Cal27 (a) and FaDu (b), (c) head and neck cancer cell lines 
2 Gy. U251 and U87 cells, which survived 48 hours post irradiation under hypoxic conditions, showed a significant increase of OPN expression 48 hours after irradiation compared with cells in the normoxic control group (Fig. 2). Interestingly, in both glioblastoma cell lines a trend for a reduced osteopontin content was seen under normoxic conditions after 48 hours irrespective of irradiation (Fig. 2). Beta-actin and GAPDH were used as loading controls, respectively. The missing protein bands of $\beta$-actin (and GAPDH, data not shown) in lysates of Cal 27 cells, grown under hypoxic conditions, can be explained by the altered expression of housekeeping genes under hypoxia in some cell lines $[18,19]$.

\section{Effect of hypoxia and irradiation on OPN expression - mRNA level}

To assess hypoxia induced effects alone or in combination with irradiation (2 Gy or 8 Gy) on OPN mRNA levels qPCR was performed. Cal 27 cells showed a trend towards increased OPN mRNA levels (up to 12 fold, $\mathrm{p}=$ $0.2)$ under hypoxic conditions, which was slightly reduced by irradiation. In FaDu cells hypoxia $\left(0.1 \% \mathrm{O}_{2}\right)$ caused an insignificant increase in OPN mRNA levels, which was hardly influenced by irradiation. Since the
Cal27 cells did not survive under $0.1 \% \mathrm{O}_{2}$ concentration for more than 24 hours (the time point of irradiation) we conducted the experiments under less hypoxic conditions with $1 \% \mathrm{O}_{2}$. Otherwise irradiation and growing the cells $24 \mathrm{~h}$ post irradiation would not be possible. For a better comparability of the hypoxic treatment we repeated the western blot and qPCR analysis in the $\mathrm{FaDu}$ cell line with $1 \% \mathrm{O}_{2}$. We observed comparable results in osteopontin expression whether the cells were treated with $0.1 \%$ or $1 \% \mathrm{O}_{2}$ in the FaDu cell line (Fig. 3).

In contrast there was a decrease in OPN mRNA levels in the glioblastoma cell lines when cells were cultured under standard hypoxia (see Fig. 4: 24 h post irradiation), which was more pronounced the longer the cells were in culture (see Fig. 4: $48 \mathrm{~h}$ post irradiation) (p-values $<0.05$ ). Doses of 2 Gy led to a non-significant increase of OPN mRNA expression under hypoxic conditions (Fig. 4).

To confirm hypoxic culture conditions, quantitative real-time PCR for CA IX expression (which is HIF- $1 \alpha$ dependent and up-regulated under hypoxia) was performed. FaDu and U251 cells showed a clear increase (30-60 fold) of CA IX expression under hypoxic conditions. Cal27 and U87 cells reacted to hypoxia with a 2fold and 5-fold increase, respectively (data not shown).

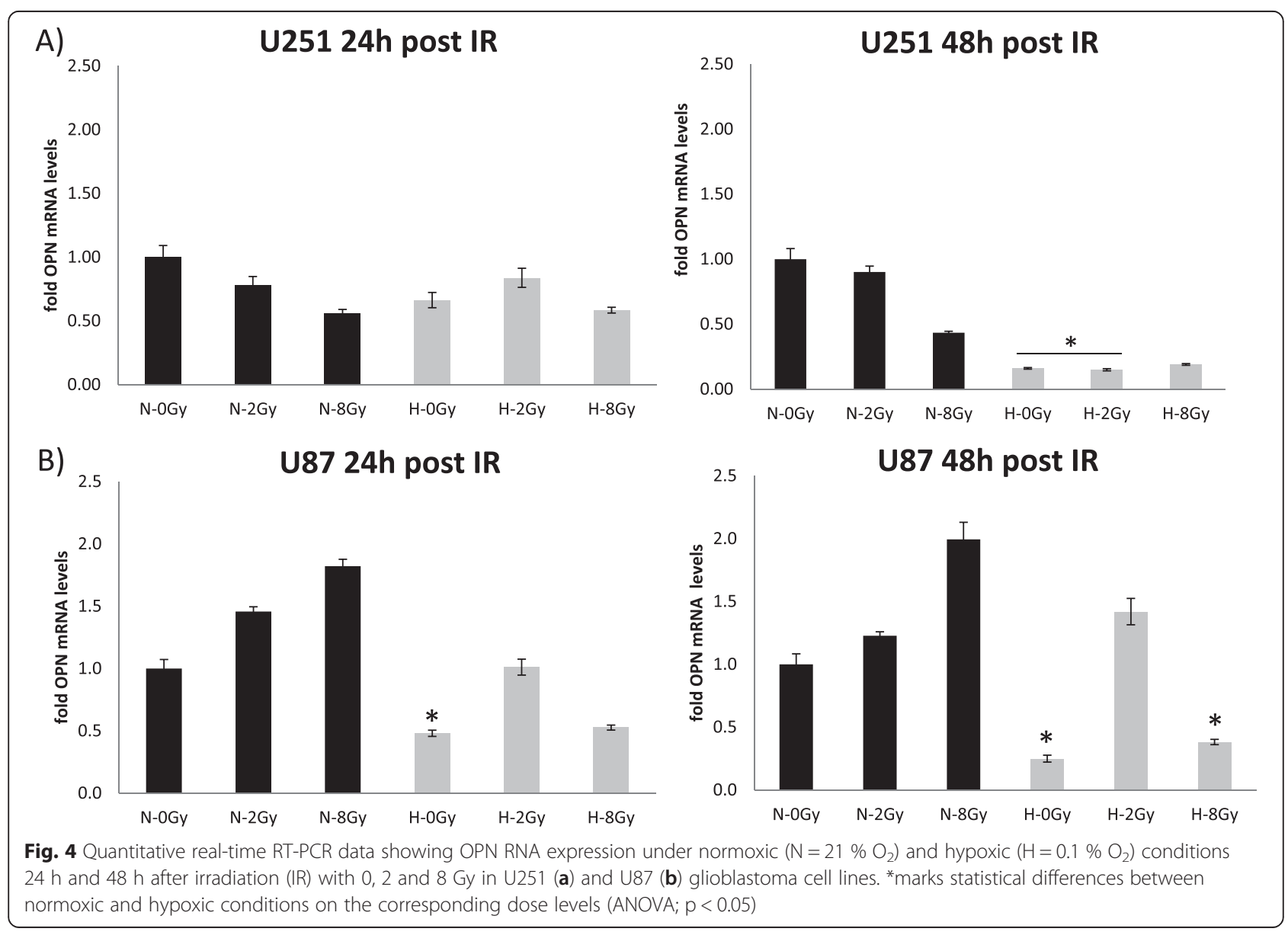


Changes in CA IX expression under hypoxia were statistically significant in all cell lines.

\section{Effect of hypoxia and irradiation on OPN secretion into cell culture medium}

For detection of osteopontin we used a commercial ELISA system without further preparation (e.g. concentration) of the cell supernatants. There was no secreted osteopontin detectable in the supernatants of the two head and neck cancer cell lines Cal27 and FaDu (data not shown). U251 and U87 cells were actively secreting osteopontin which was reduced under hypoxic conditions at $24 \mathrm{~h}$ and $48 \mathrm{~h}$ (means time after irradiation). In U87 cells this reduction reached statistical significance $(p<0.05)$. In the same cell line there was a slight increase in OPN concentrations after irradiation with 8 Gy after 48 hours compared to 0 and 2 Gy under hypoxic conditions which was not statistically significant (Fig. 5).

\section{Discussion}

Osteopontin plays a critical role in cancer progression by binding and activating different $\alpha v \beta$ - integrins and CD44 receptors. Via intracellular signaling this leads to an increase in cancer cell motility, enhanced proliferation, anchor independence growth and other steps necessary for metastasis formation. A recent overview of this multifunctional protein and other members of the matricellular protein family is given by Chong et al. [10]. In head and neck cancer as well as in glioblastoma patients osteopontin has been shown to have prognostic impact where high osteopontin plasma levels were associated with worse outcome [11, 13, 14]. In previous work we showed in different cancer cell lines that silencing osteopontin expression resulted in enhanced radiosensitivity [20-22]. This was also true for the U251 glioblastoma cell line where we observed an osteopontin dependent decrease in cell proliferation, migration and apoptotic activity and finally in a reduced clonogenic survival [14]. Induction of OPN after irradiation was seen by Chang et al. in A549 cells by p53 signaling which in the end led to an inhibition of the apoptotic pathway and resulted in more radio-resistant tumor cells [23].

In our experiments tumor hypoxia was associated with elevated OPN expression. In in-vivo trials osteopontin expression was correlated with tumor hypoxia measured invasively with the Eppendorf electrode in head and neck and lung cancer patients [24, 25]. Hence, osteopontin signaling may serve as an endogenous biomarker for tumor hypoxia and a possible intrinsic target. In a panel of standardized in-vitro cell lines we confirmed increased OPN protein expression during hypoxia. Irradiation itself did not change this pattern significantly when studied 24
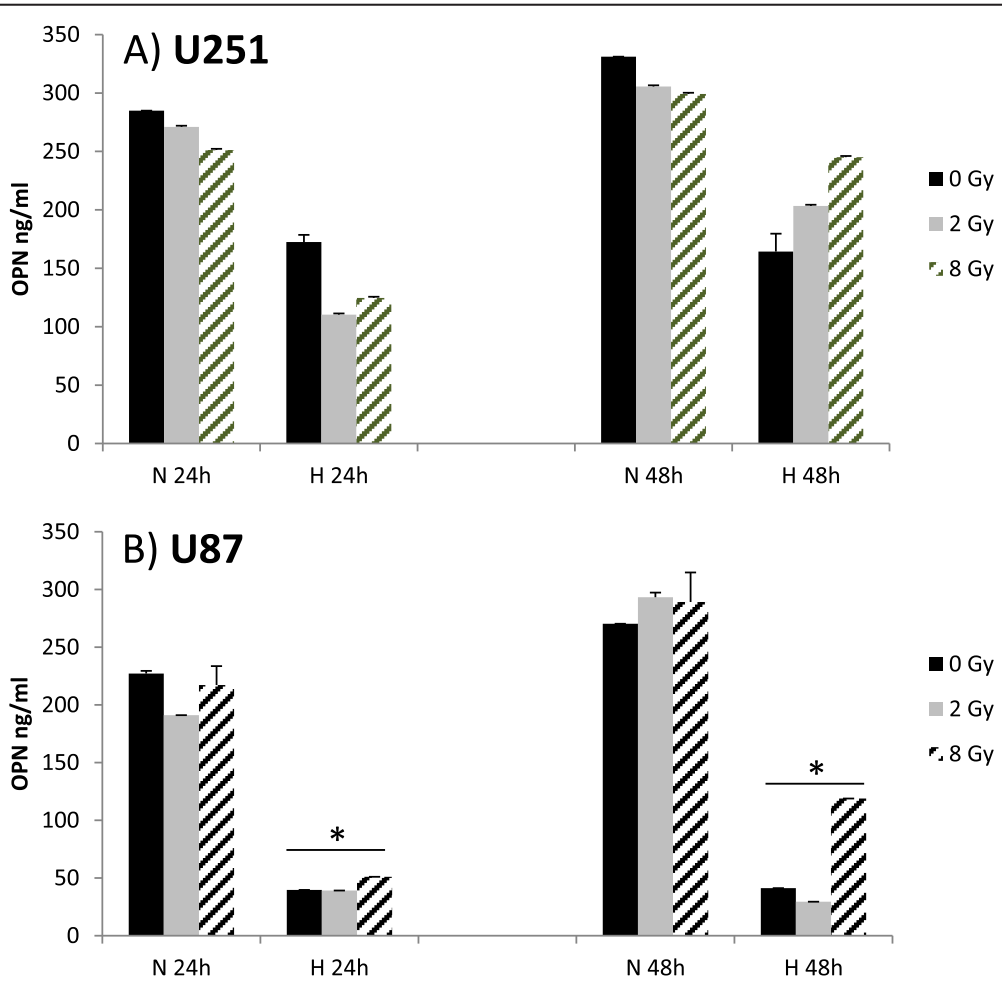

Fig. 5 ELISA from cell culture supernatants showing OPN-concentrations under normoxic $\left(\mathrm{N}=21 \% \mathrm{O}_{2}\right)$ and hypoxic $\left(\mathrm{H}=0.1 \% \mathrm{O}_{2}\right)$ conditions $24 \mathrm{~h}$ and $48 \mathrm{~h}$ after irradiation with 0,2 and $8 \mathrm{~Gy}$ in U251 (a) and U87 (b) glioblastoma cell lines. *marks significant differences between normoxic and hypoxic conditions with $p<0.05$ for 24 and 48 hours 
and 48 hours after hypoxic challenge. This was also observed in a breast cancer cell line after irradiation with 2 Gy [22]. If an increase in OPN expression would have been observed this could be beneficial for tumor cell survival and may reduce treatment response. This may result in an increase in radio-resistance.

Unexpectedly, in glioblastoma cell lines a considerable decrease in osteopontin secretion (40-85 \%) under hypoxic conditions with only a slight increase when cells were irradiated. A decrease in OPN transcription rates were seen in our qPCR experiments. The reduction of transcriptional activity of OPN mRNA might be an effect of a negative feed-back loop due to intracellular accumulation of osteopontin protein. This assumption is supported by the observation that intracellular OPN protein levels increase while active secretion was reduced by hypoxia. An intense literature search for OPN expression patterns under irradiation and hypoxia did not reveal a comparable paper in glioblastoma. A recent paper by our group showed an increased OPN mRNA expression in glioblastoma tumor tissue compared to adjacent non tumor tissue. This is in contrast to our findings in our cell culture model, since we experienced a decrease of OPN mRNA in the two glioblastoma cell lines [26]. To elucidate whether the decrease of OPN mRNA or the intracellular increase of OPN protein has an effect on cell proliferation, migration or clonogenic survival further experiments will be done by our group in the near future. It would also be interesting to know, if the reduced secretion of OPN can reduce functional activity of the cells in an autocrine manner. We could demonstrate in previously published articles in lung, breast and endometrial cancer cell lines that silencing osteopontin expression resulted in reduced cell proliferation, cell migration and enhanced radiosensitivity [20-22]. This was also true for the U251 glioblastoma cell line where we observed an osteopontin dependent decrease in cell proliferation, migration and apoptotic activity and finally in a reduced clonogenic survival [14].

A different expression pattern was seen in the two head and neck cancer cell lines. No secretion of osteopontin at baseline and after treatment with hypoxia or irradiation was detected in cell culture supernatants (data not shown). Likewise, Hui et al. detected OPN in supernatants in only one of four evaluated nasopharyngeal cell lines. In their hands OPN secretion was not affected by hypoxic treatment [27]. In our study higher protein levels were correlated with increasing OPN mRNA expression under hypoxia in Cal27 and to a lesser degree in FaDu cells. Hypoxia enhanced osteopontin expression in head and neck cancer cells was already demonstrated by Zhu et al. who described a hypoxia associated element in the osteopontin promotor region regulated by a Ras enhanced activator [28].
In a next step we are going to analyze intracellular signaling of osteopontin under these experimental conditions and will evaluate functional activity of the tumor cells via proliferation, migration and survival assays.

\section{Conclusions}

In conclusion, osteopontin expression is strongly modulated by hypoxia and only to a minor extent by irradiation. Intracellular OPN homeostasis seems to vary considerably between cell lines and differ between mRNA and protein expression. This may explain the partly conflicting results concerning response prediction and prognosis in the clinical setting.

\section{Competing interests}

The authors declare that they have no competing interests.

\section{Authors' contributions}

GW carried out the experiments and analysis. Together with BP they drafted the manuscript. AS provided the head \& neck cancer cell lines and took part in the interpretation of the aPCR data. AG, DV and SK participated in analysis and interpretation of the data and drafted the manuscript. FM critically reviewed the article. All authors read and approved the final manuscript.

\section{Acknowledgements}

We thank Jeanette Roller (Department of Oto-Rhino-Laryngology) for advice with $\mathrm{QPCR}$.

\section{Author details}

${ }^{1}$ Department of Radiation Oncology, University hospital Wuerzburg, Josef-Schneider-Straße 11, 97080 Würzburg, Germany. ${ }^{2}$ Department of Oto-Rhino-Laryngology, Plastic, Aesthetic and Reconstructive Head and Neck Surgery, University hospital Wuerzburg, Wuerzburg, Germany. ${ }^{3}$ Department of Radiotherapy, Martin-Luther-University Halle-Wittenberg, Halle, Saale, Germany. ${ }^{4}$ Research Unit of Radiation Cytogenetics, Helmholtz-Zentrum München, German Research Center for Environmental Health, Neuherberg, Germany.

Received: 12 May 2015 Accepted: 22 July 2015

Published online: 12 August 2015

\section{References}

1. Vaupel P, Mayer A. Hypoxia in cancer: significance and impact on clinical outcome. Cancer Metastasis Rev. 2007;26(2):225-39.

2. Bittner Ml, Grosu AL. Hypoxia in Head and Neck Tumors: Characteristics and Development during Therapy. Frontiers in oncology. 2013;3:223.

3. Thorwarth D, Monnich D, Zips D. Methodological aspects on hypoxia PET acquisition and image processing. Q J Nucl Med Mol Imaging. 2013;57(3):235-43.

4. Halmos GB, Bruine De Bruin L, Langendijk JA, Van Der Laan BF, Pruim J, Steenbakkers RJ. Head and neck tumor hypoxia imaging by 18 F-fluoroazomycin-arabinoside (18 F-FAZA)-PET: a review. Clin Nucl Med. 2014;39(1):44-8.

5. Ostheimer C, Bache M, Guttler A, Kotzsch M, Vordermark D. A pilot study on potential plasma hypoxia markers in the radiotherapy of non-small cell lung cancer. Osteopontin, carbonic anhydrase IX and vascular endothelial growth factor. Strahlenther Onkol. 2014;190(3):276-82.

6. Said HM, Hagemann C, Staab A, Stojic J, Kuhnel S, Vince GH, et al. Expression patterns of the hypoxia-related genes osteopontin, CA9, erythropoietin, VEGF and HIF-1alpha in human glioma in vitro and in vivo. Radiother Oncol. 2007:83(3):398-405.

7. Vergis R, Corbishley CM, Norman AR, Bartlett J, Jhavar S, Borre M, et al. Intrinsic markers of tumour hypoxia and angiogenesis in localised prostate cancer and outcome of radical treatment: a retrospective analysis of two randomised radiotherapy trials and one surgical cohort study. Lancet Oncol. 2008;9(4):342-51. 
8. Bache M, Reddemann R, Said HM, Holzhausen HJ, Taubert H, Becker A, et al. Immunohistochemical detection of osteopontin in advanced head-andneck cancer: prognostic role and correlation with oxygen electrode measurements, hypoxia-inducible-factor-1alpha-related markers, and hemoglobin levels. Int J Radiat Oncol Biol Phys. 2006;66(5):1481-7.

9. Bellahcene A, Castronovo V, Ogbureke KU, Fisher LW, Fedarko NS. Small integrin-binding ligand N-linked glycoproteins (SIBLINGs): multifunctional proteins in cancer. Nat Rev Cancer. 2008;8(3):212-26.

10. Chong HC, Tan CK, Huang RL, Tan NS. Matricellular proteins: a sticky affair with cancers. J Oncol. 2012;2012:351089.

11. Petrik D, Lavori PW, Cao H, Zhu Y, Wong P, Christofferson E, et al. Plasma osteopontin is an independent prognostic marker for head and neck cancers. J Clin Oncol. 2006;24(33):5291-7.

12. Mack PC, Redman MW, Chansky K, Williamson SK, Farneth NC, Lara Jr PN, et al. Lower osteopontin plasma levels are associated with superior outcomes in advanced non-small-cell lung cancer patients receiving platinum-based chemotherapy: SWOG Study S0003. J Clin Oncol. 2008:26(29):4771-6.

13. Overgaard J, Eriksen JG, Nordsmark M, Alsner J, Horsman MR. Plasma osteopontin, hypoxia, and response to the hypoxia sensitiser nimorazole in radiotherapy of head and neck cancer: results from the DAHANCA 5 randomised double-blind placebo-controlled trial. Lancet Oncol. 2005;6(10):757-64.

14. Guttler A, Giebler M, Cuno P, Wichmann H, Kessler J, Ostheimer $C_{\text {, et al. }}$ Osteopontin and splice variant expression level in human malignant glioma: radiobiologic effects and prognosis after radiotherapy. Radiother Oncol. 2013;108(3):535-40

15. Likui W, Hong W, Shuwen Z. Clinical significance of the upregulated osteopontin mRNA expression in human colorectal cancer. J Gastrointest Surg. 2010;14(1):74-81.

16. Snitcovsky I, Leitao GM, Pasini FS, Brunialti KC, Mangone FR, Maistro S, et al. Plasma osteopontin levels in patients with head and neck cancer undergoing chemoradiotherapy. Archives of otolaryngology-head \& neck surgery. 2009;135(8):807-11.

17. Lim AM, Rischin D, Fisher R, Cao H, Kwok K, Truong D, et al. Prognostic Significance of Plasma Osteopontin in Patients with Locoregionally Advanced Head and Neck Squamous Cell Carcinoma Treated on TROG 02.02 Phase III Trial. Clin Cancer Res. 2012;18(1):301-7.

18. Caradec J, Sirab N, Keumeugni C, Moutereau S, Chimingqi M, Matar C, et al. 'Desperate house genes': the dramatic example of hypoxia. Br J Cancer. 2010;102(6):1037-43

19. Zhong $H$, Simons JW. Direct comparison of GAPDH, beta-actin, cyclophilin, and $28 \mathrm{~S}$ rRNA as internal standards for quantifying RNA levels under hypoxia. Biochem Biophys Res Commun. 1999;259(3):523-6.

20. Polat B, Wohlleben G, Katzer A, Djuzenova CS, Technau A, Flentje M. Influence of osteopontin silencing on survival and migration of lung cancer cells. Strahlenther Onkol. 2013;189(1):62-7.

21. Hahne JC, Meyer SR, Kranke P, Dietl J, Guckenberger M, Polat B, et al. Studies on the role of osteopontin-1 in endometrial cancer cell lines. Strahlenther Onkol. 2013;189(12):1040-8.

22. Hahnel A, Wichmann H, Kappler M, Kotzsch M, Vordermark D, Taubert H, et al. Effects of osteopontin inhibition on radiosensitivity of MDA-MB-231 breast cancer cells. Radiat Oncol. 2010;5:82.

23. Chang SH, Minai-Tehrani A, Shin JY, Park S, Kim JE, Yu KN, et al. Beclin1induced Autophagy Abrogates Radioresistance of Lung Cancer Cells by Suppressing Osteopontin. J Radiat Res. 2012;53(3):422-32.

24. Le QT, Kong C, Lavori PW, O'Byrne K, Erler JT, Huang X, et al. Expression and prognostic significance of a panel of tissue hypoxia markers in head-and-neck squamous cell carcinomas. Int J Radiat Oncol Biol Phys. 2007:69(1):167-75.

25. Le QT, Chen E, Salim A, Cao H, Kong CS, Whyte R, et al. An evaluation of tumor oxygenation and gene expression in patients with early stage nonsmall cell lung cancers. Clin Cancer Res. 2006;12(5):1507-14.

26. Bache M, Rot S, Kessler J, Guttler A, Wichmann H, Greither T, et al. mRNA expression levels of hypoxia-induced and stem cell-associated genes in human glioblastoma. Oncol Rep. 2015;33(6):3155-61.

27. Hui EP, Sung FL, Yu BK, Wong CS, Ma BB, Lin X, et al. Plasma osteopontin, hypoxia, and response to radiotherapy in nasopharyngeal cancer. Clin Cancer Res. 2008;14(21):7080-7.

28. Zhu Y, Denhardt DT, Cao H, Sutphin PD, Koong AC, Giaccia AJ, et al. Hypoxia upregulates osteopontin expression in $\mathrm{NIH}-3$ T3 cells via a Ras-activated enhancer. Oncogene. 2005;24(43):6555-63.

\section{Submit your next manuscript to BioMed Central and take full advantage of:}

- Convenient online submission

- Thorough peer review

- No space constraints or color figure charges

- Immediate publication on acceptance

- Inclusion in PubMed, CAS, Scopus and Google Scholar

- Research which is freely available for redistribution

Submit your manuscript at www.biomedcentral.com/submit 